\title{
Padina pavonica: Morphology and Calcification Functions and Mechanism
}

\author{
Miriam Benita, Zvi Dubinsky, David Iluz \\ The Mina \& Everard Goodman Faculty of Life Sciences, Bar-Ilan University, Ramat-Gan, Israel \\ Email: miriamzarbiv@gmail.com
}

How to cite this paper: Benita, M., Dubinsky, Z. and Iluz, D. (2018) Padina pavonica: Morphology and Calcification Functions and Mechanism. American Journal of Plant Sciences, 9, 1156-1168. https://doi.org/10.4236/ajps.2018.96087

Received: January 19, 2018

Accepted: May 14, 2018

Published: May 17, 2018

Copyright ( $) 2018$ by authors and Scientific Research Publishing Inc. This work is licensed under the Creative Commons Attribution International License (CC BY 4.0).

http://creativecommons.org/licenses/by/4.0/

(c) (i) Open Access

\begin{abstract}
Padina pavonica is one of the common macro-algae that inhabit coastal inter-tidal zones around the world. It is one of the two brown algae known to science today that calcifies. It precipitates $\mathrm{CaCO}_{3}$ in the microscopy form of Aragonite needle shape seen macroscopically as a vertical ventral stripes. Here we will summarize the information available since the beginning of the $20^{\text {th }}$ century, taking into consideration the algal distribution, macro and micro-morphology, cytology, reproduction, $\mathrm{CaCO}_{3}$ bio-mineralization, and a slight reference to the commercial aspects, i.e., its use in the medical and cosmetic industries. This paper discusses the likely advantages that Padina gains by the calcification and the effect of $\mathrm{pH}$ caused by global climate changes on this calcification. We will describe the distribution of Padina, while focusing on the morphology of $P$. pavonica, as described in the literature, occasionally comparing it to another common species in Tel-Baruch $-P$. gymnospora. This review is somewhat prolog for the upcoming research.
\end{abstract}

\section{Keywords}

Padina Pavonica, Morphology, Calcification, Reproduction

\section{Getting to Know Padina}

Padina pavonica is a brown alga from the Dichtyophyceae family, distributed from warm-temperate to tropical shores, at latitudes of \pm 30 worldwide, and growing mainly in the Mediterranean Sea and Atlantic Ocean [1] [2]. Today, according to ALGAEBASE.ORG, there are 72 species belonging to the genus $\mathrm{Pa}$ dina, most of which were only recently accepted taxonomically, but because of the similarity among them, it is hard to know for sure.

Along the Israeli shores, Padina sp. grows mainly on kurkar platforms (abrasion tables) [3], but it can also grow on sand-covered rocks [4]. The environ- 
ment, whether rocky or sandy, is an extreme one, characterized by very turbulent water, variable salinity, high $\mathrm{pH}$ variation, high temperatures and occasional desiccation at ebb time [5]. This alga seems to thrive under such conditions.

Padina's life cycle is considered perennial, but the thallus detaches every winter and regrows in spring [6]. During winter, the alga stays in the form of rhizoids, filamentous thalli or sporelings, until the conditions are suitable for full regrowth [7]. Like most brown algae, it has a haploid-diploid reproduction cycle [8].

Padina is quite unique because it is one of the two calcified brown algae known today (the second one being Newhousia imbricata) [2] [9] [10]. $\mathrm{CaCO}_{3}$ is precipitated in the form of needle-shaped aragonite crystals [11]. The aragonite is extra-cellular, mainly on the ventral surface of the thallus [12], and changes from needle shape into lumpy surface in the older part of the thallus, probably due to mechanical erosion [6].

$P$. pavonica has been well studied since the beginning of the last century and is, environmentally and medically, an important alga, extensively used as a feedstock for the production of biodiesel [13], in heavy-metal biosorption, as a pollution bioindicator [11], a trace metal biomonitor [14], an antioxidant [15], an anticancer drug (by inducing apoptosis of cancer cells) [16], an antibacterial agent [17], and a bioinsecticide [18].

\section{Morphology}

The Padina $s p$. body contains two parts: the thallus, which is divided into 8 , and sometimes more (Figure 1), whitish to brownish color fronds, and the holdfast, consisting of flexible rhizoids for surface attachment [4]. The fronds are fan or ear shaped, and can reach up to $15 \mathrm{~cm}$ length in summertime, becoming narrower towards the base (Figure 2(a)), reaching up to $2 \mathrm{~mm}$ width and about 1 cm length [4]. In winter, they are very small or do not grow at all [4].

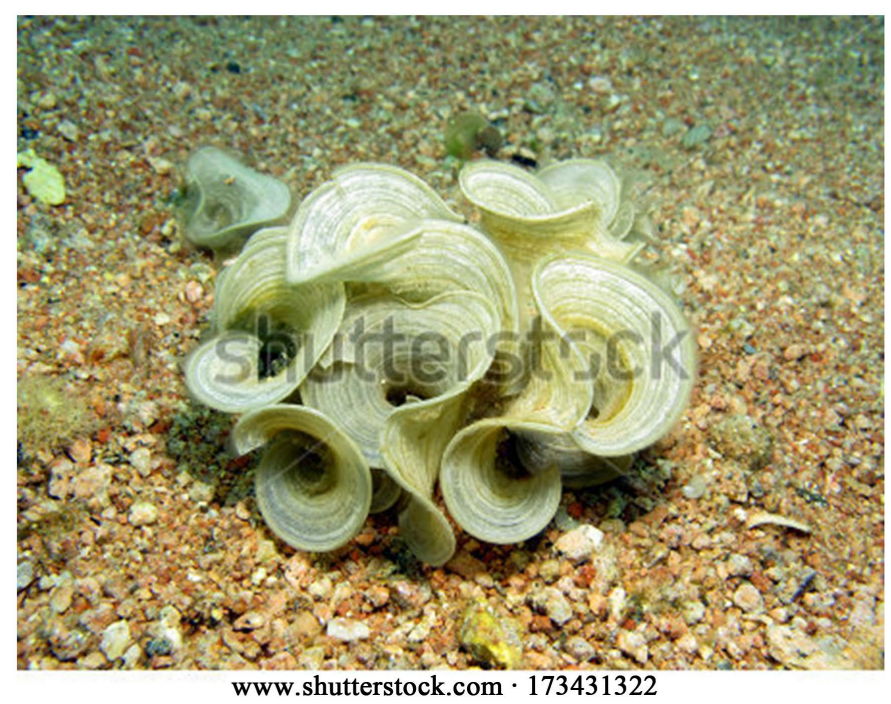

Figure 1. Padina fronds, taken from Shutterstock [44]. 


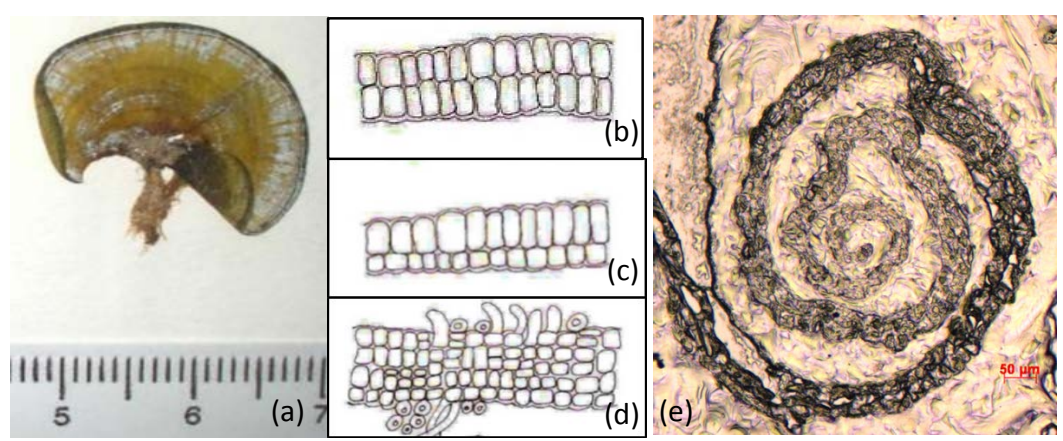

Figure 2. P. pavonica cell morphology: (a) The frond (Portuguese Seaweed Website [45]); (b) Transverse section of the upper cell layers; (c) Transverse section of the middle cell layer; (d) Transverse section of the cell layers next to the rhizoids. Scale bar $300 \mu \mathrm{m}$ [4]; and (e) The inrolled apical margin of the thallus under Axio microscopy and according to the histology protocol.

The apical tip of the fronds is inrolled (Figure 2(e)) toward the ventral part of the thallus [11]. The rolling takes place because the dorsal side grows faster than the ventral one, thereby protecting the tender young cells [19]. The growth of the frond begins from a group of marginal meristem cells [9], and expands sideways [4] [20].

The apical region of different Padina species is $60-70 \mu \mathrm{m}$ thick and consists of two cell layers, while the base is $90-115 \mu \mathrm{m}$ thick and composed of three to six cell layers [12]. In the case of $P$. pavonica, the thallus is composed of up to three layers at its base [21].

Concentric hair bands $1-2 \mathrm{~mm}$ wide are found every $2.5-3 \mathrm{~mm}$ on both sides of the thallus [21], and are more prominent on the dorsal side [19]. Abbas and Shameel [22] found no such hair lines in the species P. gymnospora along the coast of Karachi, Pakistan, but Santhanam [23] described concentric hair in both species. P. pavonica hairs are $50-80 \mu \mathrm{m}$ long, with a diameter of $6-9 \mu \mathrm{m}$, are composed of $6-12$ cells [12], and grow from cells with large nuclei and dense cytoplasm ( $P$. pavonia, Carter [19]). This happens to 4 to 8 closed cells at the same time, so that every hair area is composed of several rows [19]. These large condensed cells divide into long hairs, representing the beginning of the reproduction zone, and one of their functions is to protect the forming reproductive cells from sand [19]. The hairs can be broken off in the old thallus [19].

\section{Cytology}

The outer ventral layer of the thallus (the epidermis) which was measured on $P$. pavonica from Pakistan, contains several dense, brownish chromatophores called phaeoplasts [4]. The upper part is composed of barrel-shaped cells [11 - 23 $\mu \mathrm{m}$ wide (W)] (Figure 2(b)), and the lower part (Figure 2(c)) is composed of square $(23-46 * 23-34 \mu \mathrm{m})$ or rectangular cells [4]. The second layer (the cortex) consist of $1-4$ layers of large isodiametric, square $(23-46 * 23-34 \mu \mathrm{m})$, rarely rectangular cells, set up in transversal rows and having fewer phaeoplasts than the epidermal layer [4]. 
Toward the holdfast, the peripheral cells change into rhizoidal filaments (Figure 2(d)) that attach to a solid surface, such us stone, or are embedded in sand, and the cells between them are double walled [4].

The outer ventral cells, which were measured on $P$. pavonica from Taiwan, are the smallest, i.e., 19 - $38 \mu \mathrm{m}$ length (L) and $25-40 \mu \mathrm{m}$ height $(\mathrm{H})$. The median cells are the largest, i.e., $62-74 \mu \mathrm{m} \mathrm{L}$ and $25-45 \mu \mathrm{m} \mathrm{H}$. The inner dorsal cells are equal or smaller to the middle cells, i.e., $28-68 \mu \mathrm{m} \mathrm{L}$ and $25-30 \mu \mathrm{m} \mathrm{H}$ [12].

The apical cell line in the inrolled margin is surrounded by distinctly hair-line margins, about $0.4 \mu \mathrm{m}$ thick each [24]. When an apical cell divides, it grows tangentially into two new daughter cells [19]. The walls of both the dorsal and ventral surfaces appear identical within the inward-rolled margin [24].

Chemically, the thallic tissue is composed of polysaccharides, such as alginates, fucoidans, and cellulose [25], and the phaeoplasts are composed of 14 pigments, including chlorophyll c1, c2, fucoxanthin, fucoxanthol, flavoxanthin, and diatoxanthin [26].

\section{Reproduction}

Most brown algae have a haploid-diploid life cycle (Figure 3) [8]. This is also the case with the genus Padina, which has two separate reproductive forms: fronds can have diploidic spores or haploidic gametes [20]. In Padina pavonica, fertile sporophytes are much more common than fertile gametophytes [27]. Sporangia are assembled in concentric dark sori, covered by an obvious indusium (a thin membrane that covers the reproduction cells), and arranged between the hair bands (Figures $4(\mathrm{~b})$-(d)). It seems that the indusium is related to the hair lines and covers them too [28].

The reproductive cells are found only on the dorsal side of the thallus [1] [9] [12], usually in an un-calcified area [27]. In $P$. pavonica, there are two stripes of

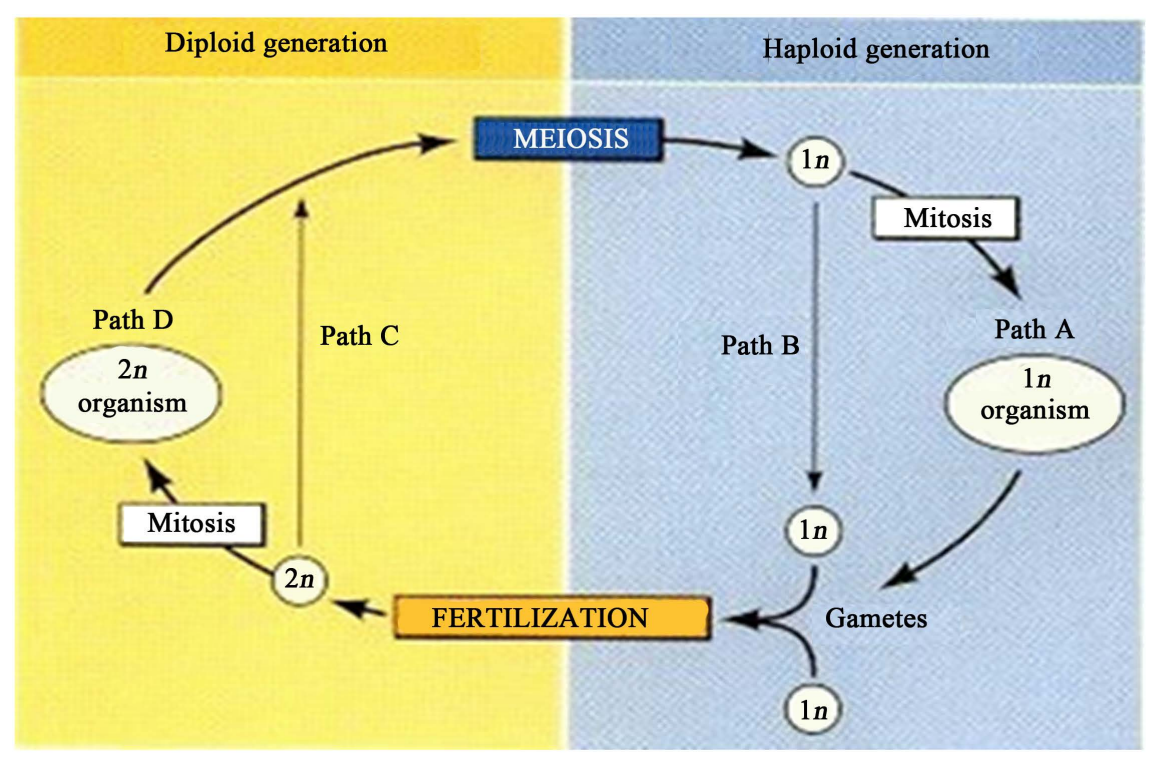

Figure 3. The reproductive haploid-diploid cycle in Phaeophyta [46]. 


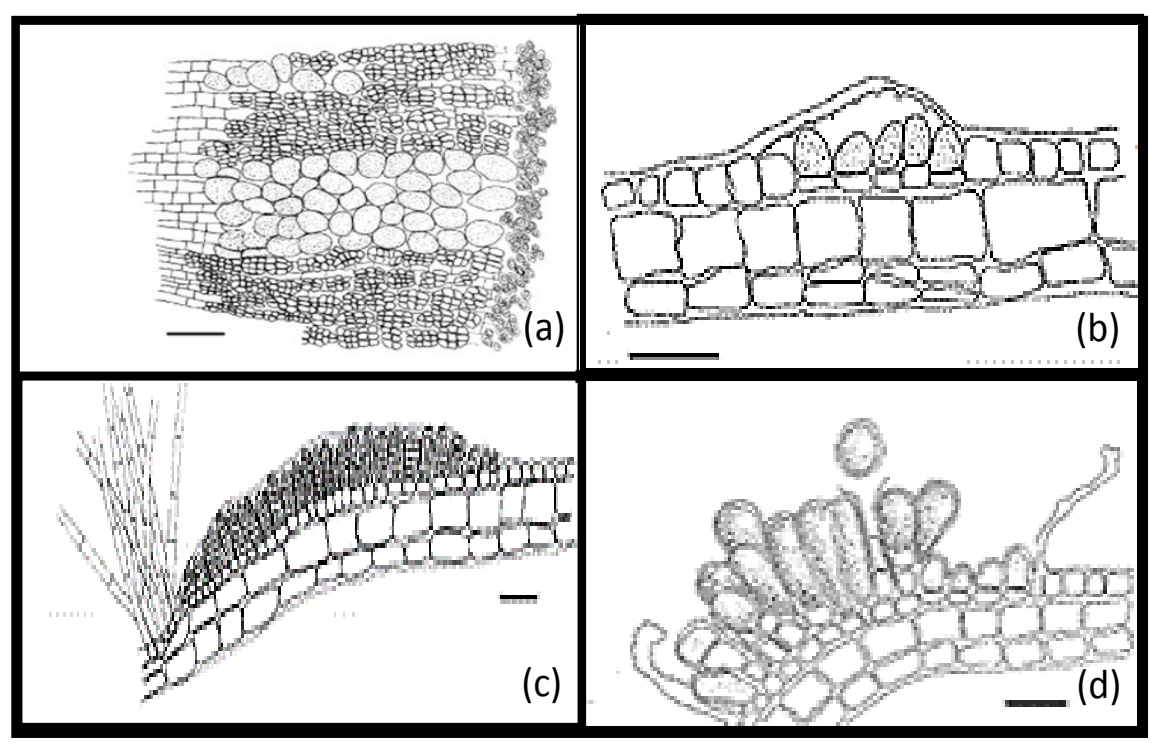

Figure 4. P. pavonica reproductive cells. (a) Radial section of monoecious sori; (b) Radial section of the indusium (arrow) over young oogonial sori; (c) Antheridial sori (with basal stalk cells and condensed hair); and (d) The indusium (arrows) torn over mature oogonial sori. Scale bar (a)-(d) $100 \mu \mathrm{m}$ [27].

reproductive cells and, as seen in Figure 5(a) and Figure 5(b), the upper (towards the apical end of the thallus) stripes are thicker than the lower ones, and are sometimes absent all together [20]. Each of the stripes contains perpendicular reproductive cell rows (Figure 5(c)) [27]. There is a gradient in the maturation of spores, i.e., the lower stripes mature before the apical ones. These are either in the meiotic division stage or fully developed, while the apical spores are still in the stalk-cell division stage [19].

Gamete expression Specimens can be monoecious, bearing both oogonia and antheridia [9] [12] (Figure 5(b)). In such a case, as found in the coasts of south-east Asia and the Mediterranean, antheridia are oval-shaped, $23-80 * 57$ $80 \mu \mathrm{m}$, and have walls (Figure 4(c)) [9]. The oogonial cells are rounded to ovoid and measure $44-178 * 39-72 \mu \mathrm{m}$ [27]. In $P$. pavonica from the Iberian coasts [27], the oogonial cells arranged in up to 4 rows, 8 - 10 oogonia per row, and the male sori in rows that contain $8-22$ antheridia. Their shape can be either ovoid or rectangular, $39-78 * 28-50 \mu \mathrm{m}$. Approximately $2 \mathrm{~mm}$ of male gametophytes ends with approximately $90 \mu \mathrm{m}$ or less of small oogonial sori (Figure 4(a)).

Padina can also be dioecious, with antheridia and oogonia on separate fronds [27] (Figure 5(a)). In dioecious fronds, female gametophyte sori are arranged in twin parallel stripes, approximately every $2.5-3 \mathrm{~mm}$. The upper twin stripes, closer to the apical end, are $290-1350 \mu \mathrm{m}$ wide, and the lower twin stripes, only $230-650 \mu \mathrm{m}$ wide. The sori grow in rows perpendicular to the hair lines. The apical contains 8 to 18 oogonia per row (Figure 5(c)), while the lower stripes contain 8 oogonia per row [27]. The Antheridia sorus is white, cylinder-shaped, $23-46 \mu \mathrm{m}$ in height and $18-33 \mu \mathrm{m}$ in diameter, on a basal stalk cell $10-21 \mu \mathrm{m}$ high, and a diameter of $10-26 \mu \mathrm{m}$ [12]. The oogonia sorus is 


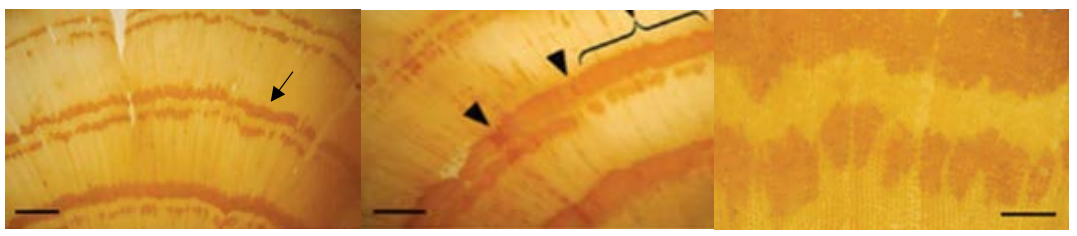

(a)

(b)

(c)

Figure 5. The sorus stripes of $P$. pavonica. (a) Dioecism, female thallus oogonia are arranged as two dark lines (arrow) [27]; (b) Monoecism, Antheridia (\{) in between narrow oogonia (arrowheads) [27]. Scale bar (a) and (b), $2 \mathrm{~mm}$; and (c) close-up of the sorus's perpendicular rows. Scale bar $400 \mu \mathrm{m}$.

brown, ovoid-shaped, $42-91 \mu \mathrm{m}$ in height and $41-63 \mu \mathrm{m}$ in diameter, with a basal stalk cell 5 - $20 \mu \mathrm{m}$ in height and $30-48 \mu \mathrm{m}$ in diameter [12].

It seems that temperature is an influential factor on the algal mode of reproduction: in warm waters, Padina tends to be mostly dioecious, while in cooler water it is predominantly monoecious. It is noteworthy that $P$. gymnospora appears to have only dioecious or tetrasporic expression [20] [29].

Both oogonia and antheridia originate from the division of cortical cells on a plane parallel to the front surface, and in the case of $P$. pavonica, covered with indusium, as seen in Figure 4(b) [27]. When the indusium is torn, it remains connected to the hair bands (Figure 4(d)) [28].

Spore expression - Spores can be up to $95-175 \mu \mathrm{m}$ high and $55-100 \mu \mathrm{m}$ in diameter [12]. They form up to 2 layers and have brownish filaments with phaeoplasts between them [9] [12]. The sporangia are born on a basal stalk cell, $6-22 \mu \mathrm{m} \mathrm{H}$ and $25-52 \mu \mathrm{m}$ in diameter [12], and when it grows, it forms many-celled sporangia, each cell containing a single spore.

In some Padina sp., there is a stage known as the Vaughaniella stage, in which a prostrate rhizome develops into a branched phase and a new erect thallus. It seems that this stage is perennial, and is not affected by change of season [9] [30]. There are conflicting views among scientists regarding whether such a stage exists in $P$. pavonica. As seen in Table 1, Ni-Ni-Win et al. [27] consider $P$. pavonica as not having this stage, while Gómez Gómez et al. [28] claim that there is a Vaughaniella stage.

It seems that the algae invest more energy in reproduction than in growth, and in an environment that cannot sustain them for too long, e.g., sandy beaches, the algae are smaller and have more gametophytes, because their survival time is shorter, and they can de-attached faster than on solid rocks [7].

\section{Species Determination}

Determination and identification of Padina species only by sight is difficult, and sometime even impossible. In the past, scientists determined if a species was new based on the following morphological features:

1) The structure, position, and arrangement of hair lines and reproductive sori;

2) The presence or absence of rhizoid-like groups of hairs and the presence or absence of indusium; 
Table 1. Comparison of morphological features among three-layered species and the two new Padina species together with their genetically closest species $P$. pavonica [1]. The significant differences between $P$. pavonica and $P$. pavonicoids marked in red and P. pavonica characters are bolded. ${ }^{\star}$ According to Carter [19] and Ramon and Friedmann [20]; pavonica is dioecious.

\begin{tabular}{|c|c|c|c|c|c|c|}
\hline Characteristics & P. ditristromatica & P. pavonicoides & P. boergesenii & P. fraseri & P. tristromatica & P. pavonica \\
\hline \multicolumn{7}{|c|}{ Vegetative characters } \\
\hline \multicolumn{7}{|c|}{ Thallus } \\
\hline Shape & Flabelliform & $\begin{array}{l}\text { Semicircular or } \\
\text { circular }\end{array}$ & Flabelliform & Flabelliform & Flabelliform & $\begin{array}{l}\text { Semicircular } \\
\text { or circular }\end{array}$ \\
\hline $\begin{array}{l}\text { Calcification on } \\
\text { lower/ upper } \\
\text { surfaces }\end{array}$ & Moderate/heavy & No or light/light & Moderate/moderate & Light/heavy & No or light/light & No or light/light \\
\hline \multicolumn{7}{|c|}{ Number of cell layers } \\
\hline $\begin{array}{l}\text { Marginal portion } \\
\text { (inrolled margin) }\end{array}$ & $2(2)$ & $3(2)$ & $3(2)$ & $3(2)$ & $3(2)$ & $3(2)$ \\
\hline Middle portion & A mixture of 2 and 3 & 3 & 3 & 3 & 3 & 3 \\
\hline Basal portion & A mixture of 2 and 3 & 3 & 3 & 3 & 3 & $3-4$ \\
\hline \multicolumn{7}{|c|}{ Other characters } \\
\hline $\begin{array}{l}\text { Thickness } \\
\text { of cell layers }\end{array}$ & $\begin{array}{l}\text { Same thickness at } \\
\text { 3-layer portion; and } \\
\text { cells of upper layer } \\
\text { twice as tall as those } \\
\text { of lower layer at } \\
\text { 2-layer portion }\end{array}$ & $\begin{array}{l}\text { Same thickness from } \\
\text { the margin to middle } \\
\text { portion; central cell } \\
\text { layer twice as tall } \\
\text { as the surface layers } \\
\text { at the basal portion }\end{array}$ & $\begin{array}{l}\text { Cells of lower } \\
\text { layer taller than } \\
\text { those of upper layer; } \\
\text { central cell layer } \\
\text { shorter than } \\
\text { the surface layers }\end{array}$ & $\begin{array}{l}\text { Central cell } \\
\text { layer tallest }\end{array}$ & $\begin{array}{l}\text { Central cell layer } \\
\text { shorter than the } \\
\text { surface layers }\end{array}$ & $\begin{array}{l}\text { Central cell layer } \\
\text { tallest at } 3 \text { layer } \\
\text { portion; same } \\
\text { thickness at } \\
\text { 4-layer portion }\end{array}$ \\
\hline $\begin{array}{c}\text { "Vaughaniella" } \\
\text { stage }\end{array}$ & Absent & Absent & Present & Absent & Absent & Absent* \\
\hline \multicolumn{7}{|c|}{ Hair lines } \\
\hline $\begin{array}{l}\text { Arrangement of } \\
\text { alternating hair } \\
\text { lines between } \\
\text { both surfaces }\end{array}$ & Unequal distance & Equal distance & Equal distance & Equal distance & - & Equal distance \\
\hline $\begin{array}{l}\text { Hair lines (lower/ } \\
\text { upper surfaces) }\end{array}$ & $\begin{array}{l}\text { Conspicuous/ } \\
\text { conspicuous }\end{array}$ & $\begin{array}{c}\text { Moderate/ } \\
\text { inconspicuous }\end{array}$ & $\begin{array}{l}\text { Conspicuous/ } \\
\text { conspicuous }\end{array}$ & $\begin{array}{l}\text { Conspicuous/ } \\
\text { conspicuous }\end{array}$ & $\begin{array}{l}\text { Conspicuous/ } \\
\text { inconspicuous }\end{array}$ & $\begin{array}{l}\text { Moderate/ } \\
\text { inconspicuous }\end{array}$ \\
\hline $\begin{array}{c}\text { Structures } \\
\text { (lower/ upper } \\
\text { surfaces) }\end{array}$ & $\begin{array}{l}\text { Broad-depressed/ } \\
\text { narrow-undepressed }\end{array}$ & $\begin{array}{l}\text { Broad-slightly } \\
\text { depressed/narrow- } \\
\text { undepressed }\end{array}$ & $\begin{array}{l}\text { Narrow- } \\
\text { undepressed/ } \\
\text { narrow- } \\
\text { undepressed }\end{array}$ & $\begin{array}{l}\text { Narrow- } \\
\text { undepressed/ } \\
\text { narrow- } \\
\text { undepressed }\end{array}$ & -/narrow & $\begin{array}{l}\text { Narrow-undepressed/ } \\
\text { narrow-undepressed }\end{array}$ \\
\hline \multicolumn{7}{|c|}{ Reproductive characters } \\
\hline $\begin{array}{l}\text { Reproductive } \\
\text { system }\end{array}$ & Dioecious & Dioecious & Dioecious & Dioecious & Dioecious & Monoecious* \\
\hline \multicolumn{7}{|c|}{ Sporangial sori } \\
\hline Position (surface) & Lower & Lower & Lower & Upper & Lower & Lower \\
\hline Structure & Narrow & Narrow & Narrow & Broad & Narrow & $\begin{array}{l}\text { Broad above hair } \\
\text { lines, narrow } \\
\text { below hair lines }\end{array}$ \\
\hline
\end{tabular}




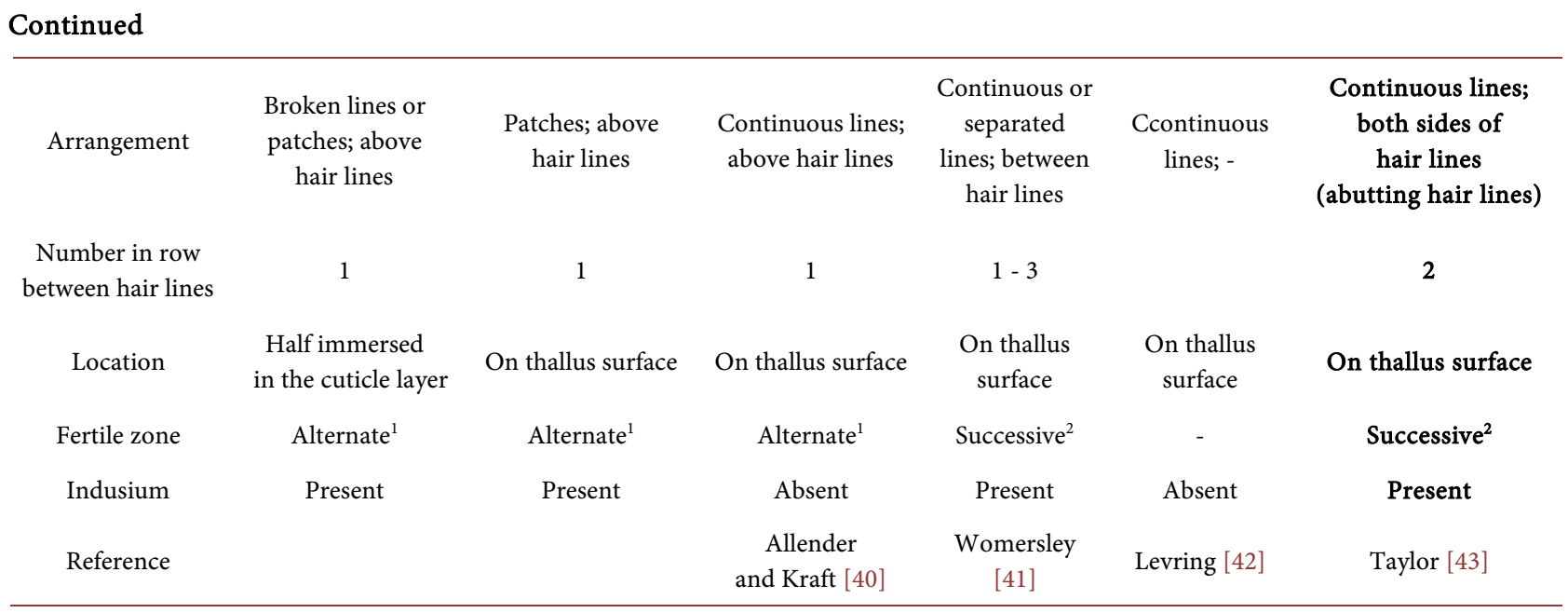

${ }^{1}$ Fertile zone separated by sterile zone when both surfaces are viewed together. ${ }^{2}$ Sterile zone absent.

3) The characteristics related to degree of calcification [1].

The reason for the difficulties in the identification is the lack of molecular data for the Padina species, which recently starting to become clearer as molecular data are starting to be added.

During the last few years, scientists have been using the RUBISCO gene sequence and the maternal $\operatorname{cox} 3$ in order to understand the phylogeny and taxonomy of brown algae [1]. In their study, they identified two new species, one of them is Padina pavonicoides, which, according to Ni-Ni-Win et al. [1], differs from $P$. pavonica in some features, as shown in Table 1 . The most significant differences are the monoeciousis, the arrangement of the sporangial sori in continuous lines, and the fact that they are on both sides of the hair lines [27], along with the successive fertile zone in $P$. pavonica [1].

From Table 1 and from the cross-combination of the two sequences, cox 3 and $r b c L$, the writers describe the two new species of Padina, and that the P. pavonicoides is a "sister" to $P$. pavonica. There was a $1.67 \%-1.98 \%$ divergence between $P$. pavonicoides and $P$. pavonica in $r b c L$ sequences, and $5.74 \%-9.05 \%$ in cox3.

In a previous study by Lee and Bae [31], the Dictyotacheae family was divided into two tribes, Dictyoteae and Zonarieae, which according to the $r b c L$ sequence and 18 s rDNA suggest that Padina belongs to Zonarieae rather than the Dictyoteae tribe.

\section{Calcification}

Padina pavonica deposits needle-shaped aragonite crystals [11] [32] at the rate of approximately $240 \mathrm{~g} \cdot \mathrm{m}^{-2} \cdot \mathrm{y}^{-1}$, which is higher than the other erect calcified algae [10] [32]. At the macro level, the aragonite settles as noticeable bright ventral stripes while the reproductive stripes are in the dorsal lower part, not always in correlation with the aragonite stripes [24]. There is more calcification on the ventral side of the algae than on the dorsal face, although at the margin area, it appears on both sides [24]. At the micro level, the aragonite needles are distri- 
buted randomly among the cells, i.e., the intercellular space [24] [33]. The needles are up to $4 \mu \mathrm{m}$ long and $0.4 \mu \mathrm{m}$ wide, isolated from sea water by a utricle outer layer. It seems that the needles co-form along with the chloroplast and with the fusion of the utricle, which is closely appressed to the needles [33].

Calcification of the frond amounts to approximately $11 \%$ content by dry weight, and is slightly lower in the old and new areas of the thallus, peaking in the middle [24]. It seems that those areas, i.e., mid-thallus, are more calcified than the margin and rhizoid areas [24], and that the aragonite crystals lose their needle shape in the older part of the thallus [33]. Calcification in the dark is slightly less than in the light [24], suggesting that photoperiods could be an influence. It seems to start in the inrolled edge, and since the chloroplasts also occur within this region, it implies an interaction between the initiation of the calcification and that of photosynthesis [24].

$\mathrm{CO}_{2}$ concentration in the water, which has been increasing since the industrial revolution, lowered the $\mathrm{pH}$ levels by 0.1 unit compared with the preindustrial revolution values, and a further decrease of $0.3-0.4$ units by the year 2100 is predicted [10]. At the coastline, there is also a diurnal fluctuation of $\mathrm{pH}$, ranging from 7.5 up to 9.0. In general, low $\mathrm{pH}$ values result in decreasing calcium carbonate saturation levels, and cause sea organisms in general, and Padina in particular, to decalcify. The same occurs near underwater $\mathrm{CO}_{2}$ vents, where the aragonite spines get thinner [10]. Padina does not seem to have a problem growing in acid conditions, like those found next to the Panarea vent [34]. In spite of the low $\mathrm{pH}$ induced decalcification, it shows resilience under acute $\mathrm{pH}$ changes, and this resilience makes it a suitable bioindicator of ocean acidification (OA) in coastal habitats [32]. This resilience occurs because the saturation levels of aragonite in the water is lower ( $\Omega$ aragonite is 3 - 4, high $\Omega=$ low saturation levels) than the magnesium calcite levels ( $\Omega$ calcite 2 - 3, low $\Omega=$ high saturation levels), i.e., it needs less $\mathrm{Ca}^{2+}$ saturated in the water to precipitate aragonite than it needs to precipitate calcite, meaning that Padina is more resilient to $\mathrm{pH}$ changes than calcite precipitating organisms, such us corals and some plankton [10]. In addition, in the presence of $\mathrm{Mg}^{2+}$, as well as other doubly charged ions in the water, the formation of an aragonite form of $\mathrm{CaCO}_{3}$ is more favored than the formation of calcite [35] [36].

\section{Calcification under Low pH}

At low $\mathrm{pH}$, the aragonite morphology changes until it completely dissolves [6]. Even the calcified epiphytes (e.g., Foraminifera) that grow on the fronds decalcify at low levels of $\mathrm{pH}$ caused by high $\mathrm{CO}_{2}$ levels [6]. Gil-Díaz et al. [32] suggested that the calcification process does not stop and that $\mathrm{pH}$ levels will dictate only whether the $\mathrm{CaCO}_{3}$ dissolves or calcifies. This implies that the calcification process, though not an obligatory one, is an ongoing process.

When exposed to a low $\mathrm{pH}$ environment, along with decalcification, the alga releases phenolic compounds from its cells. It has been suggested that these two 
responses to acidification make Padina more vulnerable to grazers, since reduced $\mathrm{CaCO}_{3}$ makes the alga more palatable, and less phenol makes the thallus more tasty [32].

\section{Photosynthesis Related to $\mathrm{CaCO}_{3}$}

As ocean acidification progresses and $\mathrm{pH}$ levels decrease, photosynthesis rates increase, probably due to the increased availability of $\mathrm{CO}_{2}$ [10]. Under OA, $P$. pavonica undergoes decalcification, concomitantly losing photo-protective phenolic compounds and decreasing its antioxidant activities [37]. Such processes were also described regarding non-calcareous algae, but unlike them, P. pavonica increases its light saturation intensity in order to adjust to the acidic environment [37].

\section{The Potential Benefits of $\mathrm{CaCO}_{3}$}

Over the years, there have been several suggestions regarding the benefits of $\mathrm{Pa}$ dina sp. calcification. Okazaki et al. [24] suggest that it gives the algae mechanical support in their high-energy environment, whereas Gil-Díaz et al. [32] think that calcification offers protection against grazers. Padilla [38] suggests that it is not protection directly against grazers, but against the tissue damage inflicted by the grazers. Burger and Schagerl [39] suggest that calcification provides protection from excess irradiance [10].

It is possible that all these suggestions are correct and that there is a synergy among the $\mathrm{CaCO}_{3}$ benefits, contributing to the success of Padina in her rough habitat.

\section{Epilog}

In summing up this review, we see a remarkable species that is well-adapted and adjusted to extreme surroundings by benefitting from a particular morphologic phenomenon, i.e., the ability to calcify aragonite needles. This ongoing research underscores the hitherto uncharted aspects of the ecophysiology of Padina, such as its optical photoprotective properties and its calcification periodicity.

\section{References}

[1] Ni-Ni-Win, Hanyuda, T., Arai, S., Uchimura, M., Prathep, A., Draisma, S.G.A., et al. (2011) A Taxonomic Study of the Genus Padina (Dictyotales, Phaeophyceae) Including the Descriptions of Four New Species from Japan, Hawaii, and the Andaman Sea. Journal of Phycology, 47, 1193-1209. https://doi.org/10.1111/j.1529-8817.2011.01054.x

[2] Silberfeld, T., Bittner, L., Fernandez-Garcia, C., Cruaud, C., Rousseau, F., De Reviers, B., et al. (2013) Species Diversity, Phylogeny and Large Scale Biogeographic Patterns of the Genus Padina (Phaeophyceae, Dictyotales). Journal of Phycology, 49, 130-142. https://doi.org/10.1111/jpy.12027

[3] Pinchasov-Grinblat, Y., Hoffman, R., Goffredo, S., Falini, G. and Dubinsky, Z. (2012) The Effect of Nutrient Enrichment on Three Species of Macroalgae as De- 
termined by Photoacoustics. Marine Science, 2, 125-131.

https://doi.org/10.5923/j.ms.20120206.03

[4] Aisha, K. and Shameel, M. (2010) Occurrence of the Genus Padina (Dictyophyceae, Phaeophycota) in the Coastal Waters of Karachi. Pakistan Journal of Botany, 42, 319-340.

[5] Befus, K.M., Cardenas, M.B., Erler, D.V., Santos, I.R. and Eyre, B.D. (2013) Heat Transport Dynamics at a Sandy Intertidal Zone. Water Resources Research, 49, 3770-3786. https://doi.org/10.1002/wrcr.20325

[6] Pettit, L.R., Smart, C.W., Hart, M.B., Milazzo, M. and Hall-Spencer, J.M. (2015) Seaweed Fails to Prevent Ocean Acidification Impact on Foraminifera along a Shallow-Water $\mathrm{CO}_{2}$ Gradient. Ecology and Evolution, 5, 1784-1793.

https://doi.org/10.1002/ece3.1475

[7] Uddin, W., Begum, M. and Siddiqui, M.F. (2015) Seasonal Growth, Development and Morphology of Two Species of Padina adanson: Padina tetrastromatica and Padina pavonica from the Manora Coast, Karachi, Pakistan. Pakistan Journal of Botany, 47, 2015-2021.

[8] Mable, B.K. and Otto, S.P. (1998) The Evolution of Life Cycles with Haploid and Diploid Phases. BioEssays, 20, 453-462.

https://doi.org/10.1002/(SICI)1521-1878(199806)20:6<453::AID-BIES3>3.0.CO;2-N

[9] Ni-Ni-Win, Hanuda, T., Draisma, S.G.A., Lim, P.E., Pang, S.M. and Kawai, H. (2013) Taxonomy of the Genus Padina (Dictyotales, Phaeophyceae) Based on Morphological and Molecular Evidences, with Key to Species Identification. Taxonomy of Southeast Asian Seaweeds, 11, 119-174.

[10] Johnson, V.R., Russell, B.D., Fabricius, K.E., Brownlee, C. and Hall-Spencer, J.M. (2012) Temperate and Tropical Brown Macroalgae Thrive, Despite Decalcification, along Natural $\mathrm{CO}_{2}$ Gradients. Global Change Biology, 18, 2792-2803.

https://doi.org/10.1111/j.1365-2486.2012.02716.x

[11] Geraldino, P.J.L., Liao, L.M. and Boo, S.M. (2005) Morphological Study of the Marine Algal Genus Padina (Dictyotales, Phaeophyceae) from Southern Philippines: 3 Species New to the Philippines. Algae, 20, 99-112. https://doi.org/10.4490/ALGAE.2005.20.2.099

[12] Wang, W.-L. (2012) Alga of Taiwan. http://algae.biota.biodiv.tw/node/582

[13] El Maghraby, D.M. and Fakhry, E.M. (2014) Lipid Content and Fatty Acid Composition of Mediterranean Macro-Algae as Dynamic Factors for Biodiesel Production. Oceanologia, 57, 86-92. https://doi.org/10.1016/j.oceano.2014.08.001

[14] Campanella, L., Conti, M.E., Cubadda, F. and Sucapane, C. (2001) Trace Metals in Seagrass, Algae and Molluscs from an Uncontaminated Area in the Mediterranean. Environmental Pollution, 111, 117-126. https://doi.org/10.1016/S0269-7491(99)00327-9

[15] Khaled, N., Hiba, M. and Asma, C. (2012) Antioxidant and Antifungal Activities of Padina pavonica and Sargassum vulgare from the Lebanese Mediterranean Coast. Advances in Environmental Biology, 6, 42-48.

[16] Stanojkovic, T.P., Savikin, K., Zdunic, G., Kljajic, Z., Grozdanic, N. and Antic, J. (2013) In Vitro Antitumoral Activities of Padina pavonica on Human Cervix and Breast Cancer Cell Lines. Journal of Medicinal Plants Research, 7, 419-424.

[17] Sahayaraj, K., Rajesh, S. and Rathi, J.M. (2012) Silver Nanoparticles Biosynthesis using Marine Alga Padina pavonica (Linn.) and Its Microbicidal Activity. Digest Journal of Nanomaterials and Biostructures, 7, 1557-1567. 
[18] Elbanna, S.M. and Hegazi, M.M. (2011) Screening of Some Seaweeds Species from South Sinai, Red Sea as Potential Bioinsecticides against Mosquito Larvae; Culex pipiens. Egyptian Academic Journal of Biological Sciences, 4, 21-30.

[19] Carter, P.W. (1927) The Life-History of Padina pavonia. I. The Structure and Cytology of the Tetrasporangial Plant. Annals of Botany, 41, 139-159. https://doi.org/10.1093/oxfordjournals.aob.a090060

[20] Ramon, E. and Friedmann, I. (1966) The Gametophyte of Padina in the Mediterranean, in Seaweed. In: Young, E.D. and McLachlan, J.L., Eds., Proceedings of the 5 th International Seaweed Symposium, Pergamon Press, Halifax, 183-196.

[21] Phillips, J.A., King, R.J., Tanaka, J. and Mostaert, A. (1993) Stoechospermum (Dictyotales, Phaeophyceae)-A Poorly Known Algal Genus Newly Recorded in Australia. Phycologia, 32, 395-398. https://doi.org/10.2216/i0031-8884-32-5-395.1

[22] Abbas, A. and Shameel, M. (2013) Occurrence of Padina gymnospora (Phaeophycota) at the Coast of Karachi. Pakistan Journal of Botany, 45, 341-344.

[23] Santhanam, R. (2014) Nutritional Marine Life. CRC Press, Boca Raton.

[24] Okazaki, M., Pentecost, A., Tanaka, Y. and Miyata, M. (1986) A Study of Calcium-Carbonate Deposition in the Genus Padina (Phaeophyceae, Dictyotales). British Phycological Journal, 21, 217-224. https://doi.org/10.1080/00071618600650251

[25] Kawai, H., Hanyuda, T., Draisma, S.G.A., Wilce, R.T. and Andersen, R.A. (2015) Molecular Phylogeny of Two Unusual Brown Algae, Phaeostrophion irregulare and Platysiphon glacialis, Proposal of the Stschapoviales ord. nov and Platysiphonaceae fam. nov. and a Re-Examination of Divergence Times for Brown Algal Orders. Journal of Phycology, 51, 918-928. https://doi.org/10.1111/jpy.12332

[26] Hegazi, M.M., Perez-Ruzafa, A., Almela, L. and Candela, M.E. (1998) Separation and Identification of Chlorophylls and Carotenoids from Caulerpa prolifera, Jania rubens and Padina pavonica by Reversed-Phase High-Performance Liquid Chromatography. Journal of Chromatography $A, 829,153-159$. https://doi.org/10.1016/S0021-9673(98)00803-6

[27] Gomez Garreta, A., J.R., L., Barcelo Marti, M.C. and Ribera Siguan, M.A. (2007) On the Presence of Fertile Gametophytes of Padina pavonica (Dictyotales, Phaeophyceae) from the Iberian Coasts. Anales del Jardin Botanico de Madrid, 64, 27-33. https://doi.org/10.3989/ajbm.2007.v64.i1.48

[28] Gomez Gomez, A., Poch, B.P., Riera Ribsa, F., Gomez Garreta, A., M.A., R.S. and Lluch, J.R. (2015) Padina ditristromatica and Padina pavonicoides (Dictyotales, Phaeophyceae): Two New Records for the Marine Benthic Flora of the Mediterranean Spanish Coasts. Cryptogamie, Algologie, 36, 55-63. https://doi.org/10.7872/crya.v36.iss1.2015.55

[29] Thivy, F. (1959) On the Morphology of the Gameyophytic Generation of Padina gymnospora (Kuetz.) Vickers. Journal of the Marine Biological Association of India, 1, 69-76.

[30] Kitayama, T. and Lin, S.-M. (2012) Brown Algae from Chaojing, Keelung City, Taiwan. Memoirs of the National Museum of Natural Science, Tokyo, 48, 149-157.

[31] Lee, W.J. and Bae, K.S. (2002) Phylogenetic Relationship among Several Genera of Dictyotaceae (Dictyotales, Phaeophyceae) Based on 18S rRNA and Partial rbcL Gene Sequences. Marine Biology, 140, 1107-1115. https://doi.org/10.1007/s00227-002-0799-4

[32] Gil-Diaz, T., Haroun, R., Tuya, F., Betancor, S. and Viera-Rodriguez, M.A. (2014) Effects of Ocean Acidification on the Brown Alga Padina pavonica: Decalcification 
Due to Acute and Chronic Events, ARTN e108630. PLoS ONE, 9, e108630. https://doi.org/10.1371/journal.pone.0108630

[33] Kerkar, V. and Untawale, A.G. (1995) Studies on Structure and Organization of Calcium-Carbonate Deposits in Algae. Current Science, 68, 843-845.

[34] Iluz, D., Fermani, S., Ramot, M., Reggi, M., Caroselli, E., Prada, F., et al. (2017) Calcifying Response and Recovery Potential of the Brown Alga Padina pavonica under Ocean Acidification. ACS Earth and Space Chemistry, 1, 316-323. https://doi.org/10.1021/acsearthspacechem.7b00051

[35] Berner, R.A. (1975) The Role of Magnesium in the Crystal Growth of Calcite and Aragonite from Sea Water. Geochimica et Cosmochimica Acta, 39, 489-494. https://doi.org/10.1016/0016-7037(75)90102-7

[36] Falini, G., Albeck, S., Weiner, S. and Addadi, L. (1996) Control of Aragonite or Calcite Polymorphism by Mollusk Shell Macromolecules. Science, 271, 67-69. https://doi.org/10.1126/science.271.5245.67

[37] Betancor, S., Tuya, F., Gil-Diaz, T., Figueroa, F.L. and Haroun, R. (2014) Effects of a Submarine Eruption on the Performance of Two Brown Seaweeds. Journal of Sea Research, 87, 68-78. https://doi.org/10.1016/j.seares.2013.09.008

[38] Padilla, D.K. (1993) Rip Stop in Marine Algae: Minimizing the Consequences of Herbivore Damage. Evolutionary Ecology, 7, 634-644. https://doi.org/10.1007/BF01237826

[39] Burger, K. (2010) Optical Properties in Relation to the Carbonate Layer and Morphological Studies of the Brown Alga Padina pavonica (L.) Thivy. Unpublished Master's Thesis, Department of Marine Biology, University of Vienna, Vienna.

[40] Allender, B.M. and Kraft, G.T. (1983) The Marine Algae of Lord Howe Island (New South Wales): The Dictyotales and Cutleriales (Phaeophyta). Brunonia, 6, 73-130. https://doi.org/10.1071/BRU9830073

[41] Womersley, H.B.S. (1987) The Marine Benthic Flora of Southern Australia, Part II. South Australian Government Printing Division, Adelaide.

[42] Levring, T. (1942) Einige Meeresalgen von den Inseln San Ambrosio und San Felix. Botaniska Notiser, 60-62.

[43] Taylor, W.R. (1960) Marine Algae of the Eastern Tropical and Subtropical Coasts of the Americas. The University of Michican Press, Ann Arbor.

[44] Shutterstock (2017). https://www.shutterstock.com

[45] Macoi, P.S.W. (2016). http://macoi.ci.uc.pt/index.php

[46] Gilbert, S.F. (2000) Plant Life Cycles, Developmental Biology. 6th Edition, Swarthmore College, Swarthmore. 